\title{
Doseljavanje na otok - suvremene migracije na otok Korčulu
}

DOI: https://doi.org/10.11567/met.33.2.1

UDK: 314.742(210.7Korčula)"20"

Prethodno priopćenje

Primljeno: 20.03.2017.

Prihvaćeno: 15.09.2017.

\author{
Marica Marinović Golubić \\ Institut društvenih znanosti Ivo Pilar, Zagreb \\ marica@pilar.hr
}

\section{SAŽETAK}

U ovom se radu, kroz studiju slučaja otoka Korčule, istraživalo pojavu novijeg doseljavanja na hrvatske otoke, odnosno doseljavanja stanovništva nakon 2000. Interes bio je usmjeren na domaće i strane useljenike koji većinu godine žive na Korčuli, odnosno kojima je otok mjesto stalnog boravka. Autoricu je zanimalo što ih dovodi na mjesta u kojima se bilježe negativni demografski trendovi, odnosno ona iz kojih se stanovništvo pretežito iseljava. Cilj rada bio je na temelju studije jednog otoka sustavno istražiti kontekst dolaska različitih migrantskih skupina, ispitati njihove razloge za preseljenje te naglasiti sve značajniju ulogu otoka u povratnim i dolaznim migrantskim tokovima. Teorijska podloga rada oslanja se na pristupe koji naglašavaju neekonomske razloge migracije (King, 2002) te migracije kao rezultat promjene životnog stila (Benson i O'Reilly, 2009a). Istraživački pristup bio je kvalitativan i uključivao je intervjue s 37 doseljenika. Osim intervjua primijenjena je i metoda ankete kako bi se dopunili demografski podaci o ispitanicima. Na temelju podataka iz intervjua i anketnih upitnika sugovornici su grupirani u tri osnovne skupine prema njihovoj glavnoj vezi s otokom: a) migranti povratnici (trinaest ispitanika), b) bračni migranti/ice (dvanaest ispitanika) i c) doseljenici - bez prethodne bračne ili rodbinske veze s otokom (dvanaest ispitanika). Na primjeru Korčule može se zaključiti kako su veći hrvatski otoci, usprkos negativnim demografskim trendovima, potencijalno privlačne destinacije za određeni broj domaćih i stranih doseljenika. Iako je teško očekivati značajniju revitalizaciju otočnog prostora, turizam svakako dovodi nove aktere u njega. Veliki otoci u povoljnijoj su poziciji s obzirom na veći broj stanovnika i veću gustoću društvenih odnosa te veću količinu sadržaja i infrastrukturne opremljenosti.

KLJUČNE RIJEČI: Korčula, otok, imigracija, migracije životnih stilova, umirovljeničke migracije, povratne migracije

\section{UVOD}

Kada razmišljamo o migracijama i hrvatskim otocima, najčešće je prva asocijacija iseljavanje i napuštanje otoka. Možda se i prisjetimo otočne živosti i gužve u ljetnim mjesecima, ali doći i ostati živjeti na otoku veći dio 
godine manje je raširena migracijska praksa na hrvatskim otocima. Ovaj rad bavi se upravo takvom pojavom - doseljavanjem na otok, točnije stanovništvom koje se u posljednjih petnaestak godina iz nekih drugih krajeva Hrvatske ili inozemstva doselilo na otok Korčulu i ondje ostalo živjeti. ${ }^{1}$

Iz dosadašnjih istraživanja novijih doseljenika na hrvatske otoke izdvojeno je nekoliko različitih tipova. S. Podgorelec i S. Klempić Bogadi (2013: 42-51) u istraživanju društvenih procesa na manjim hrvatskim otocima prepoznaju sljedeće skupine doseljenika: povratnike, dnevne i tjedne cirkulante, migrante životnog stila koji određeni dio godine žive na otocima te bračne i radne migrante. U teorijskom radu o umirovljeničkim migracijama S. Božić (2001) prepoznaje hrvatsku obalu i otoke kao potencijalno poželjna mjesta doseljavanja u prvom redu domaćih i stranih umirovljenika te piše kako se ne treba čuditi ako se njihov broj na Jadranu poveća. Empirijsku analizu umirovljeničkih migracija na hrvatskim otocima donosi M. Bara (2013) pokazujući kako je osim »klasičnih « umirovljeničkih migracija značajna i struja umirovljenika povratnika. Zanimljiv primjer postojanja kontrakulturnih migranata na hrvatskom otoku u svom radu navodi N. Bokan (2012). Istražujući ekološke mikrosocijalne zajednice u Hrvatskoj, autorica jednu takvu zajednicu nalazi i na otoku Braču te piše kako su pripadnice te zajednice »u lokalnoj sredini prošle put od društvenog neprihvaćanja do razmjerno velike mjere integracije u otočki život« (2012: 183). Kao posebnu kategoriju posjetitelja hrvatskih otoka možemo spomenuti i relativno brojnu skupinu vlasnika objekata za odmor. G.-M. Miletić (2011) analizirajući podatke prostorne razdiobe takvih objekata ustvrđuje kako se na otocima nalazi iznadprosječni broj stanova za odmor. Na ovome mjestu možemo spomenuti migracijski val koji je bio aktualan početkom devedesetih godina 20. stoljeća za vrijeme ratnih zbivanja u Hrvatskoj. Naime određeni broj izbjeglica i prognanih bio je smješten i na otocima s turističkim smještajnim kapacitetima. S. Čolić i A. Sujoldžić (1995) spominju da je samo na Hvaru bilo 985 takvih raseljenih osoba, od kojih se većina poslije vratila svojim domovima ili se odselila dalje.

Više je razloga zbog kojih bi znanstveno istraživanje doseljenika na hrvatske otoke moglo biti zanimljivo i relevantno. Otoci su primjeri tradicionalno iseljeničkih područja jer od kraja 19. stoljeća kontinuirano gube stanovništvo. Dugogodišnje iseljavanje otočnog stanovništva kao da je zamaglilo činjenicu da otoci paralelno privlače određene grupe doseljenika (iako

Istraživanje na kojem se temelji ovaj rad rađeno je u sklopu autoričine doktorske disertacije pod nazivom: Useljavanje u tradicionalno iseljenička područja - istraživanje slučaja otoka Korčule obranjenom na Filozofskom fakultetu Sveučilišta u Zagrebu. 
ne u većem broju). Drugo, novo stanovništvo svakako izaziva pozornost jer njegov utjecaj na revitalizaciju manjih zajednica kakve su otočne može biti ključan.

U ovom radu doseljavanje na otok Korčulu promatramo kroz teorijsku prizmu koja naglašava širenje spektra migracijskih motiva (King, 2002). Tvrdimo kako uobičajenim teorijama o radnim migrantima i ekonomski motiviranim migracijama nije moguće objasniti interes za doseljavanjem u demografski ispražnjena područja, ali s vrijednim kulturnim i ambijentalnim resursima, poput otoka. Sve su brojniji oni koji se na druga mjesta sele zbog ugodnije klime, ljepšega ili zdravijeg okoliša, boljega ili tek drugačijega životnog stila, a to ujedno i redefinira privlačnost prostorno i gospodarskih perifernih lokacija koje je do sada karakteriziralo iseljavanje stanovništva. Stoga je i glavni cilj ovog rada odgovoriti na pitanje tko se odlučuje doseliti na Korčulu te koje su životne okolnosti utjecale na odluku o dolasku na otok. Pritom se studija slučaja pokazala kao optimalni istraživački izbor s obzirom na to da omogućuje sagledavanje širega konteksta istraživane pojave.

U prvom dijelu rada daje se pregled teorijskih pristupa koji objašnjavaju doseljavanje $\mathrm{u}$ krajeve iz kojih se stanovništvo paralelno iseljava. Naglasak je na ideji da se predstavi širi spektar migracijskih motiva doseljenika te da odmicanjem fokusa od ekonomskih razloga migracija potencijalno privlačnim postaju mnoga manja i »nepoznata« mjesta. U drugom dijelu izlaže se dio rezultata provedenog istraživanja iz kojih se nameću tri dominantna tipa doseljenika na otok.

\section{PRISTUPI ISTRAŽIVANJU NOVIJEG DOSELJAVANJA U TRADICIONALNO ISELJENIČKA PODRUČJA}

Već je u više navrata primijećeno kako se promijenio spektar migracijskih motiva (Božić, 2001; King, 2002; Favell i Recchi, 2009; Van Hear, 2010). R. King piše kako su danas migrantski motivi puno različitiji kao i samo geografsko podrijetlo migranata, njihova odredišta, rute i načini putovanja. Tradicionalno ekonomski motiviranim radnim migracijama možemo dodati i druge migracijske razloge vezane uz životni stil, poput ideje da se »vidi svijeta«, dožive nova uzbuđenja i iskustva ili živi u ugodnijoj klimi (2002: 95). U literaturi susrećemo različite nazive za te »novije oblike« migracija kao što su umirovljeničke migracije (King, Warnes i Williams, 2000), migracije u kasnijoj životnoj dobi (Božić, 2006), migracije povezane s dokolicom (dokoličarske migracije) (Böröcz, 1996), migracije ugodnosti (Gosnell i 
Abrams, 2011), potrošačke migracije (Bell i Ward, 2000), migracije povezane s turizmom (O'Reilly, 2003; Williams i Hall, 2000), neekonomske migracije (Hoey, 2014) i mješovite migracije (Van Hear, 2010). Svi ti koncepti međusobno se isprepleću i nemaju jasnih granica (Božić, 2001: 322), ali možemo reći da su novi oblici motivacija za migraciju povezani s mijenom životnog ciklusa (npr. umirovljeničke ili studentske migracije) te mijenom životnog stila (migracija kao izraz potrošačkog društva u kojem se migracijom konzumira ugodnija klima, bolji ili ljepši i zdraviji okoliš, uzbuđenje, iskustvo, pa i novi život /King, 2012/).

Promjene vezane uz životnu dob i životni stil i prije su generirale migrantske tokove, međutim danas su prepoznate kao puno značajniji i brojniji fenomen koji se proučava pod zasebnom teorijsko-istraživačkom nišom pod nazivom migracije životnih stilova (eng. lifestyle migration). Migracije životnih stilova K. O'Reilly i M. Benson (2009: 2) definiraju kao »prostornu mobilnost relativno dobrostojećih pojedinaca svih dobi, koja može biti trajna ili povremena, na mjesta koja su im značajna jer im omogućuju veću kvalitetu života«. Prema tim autoricama, riječ je o različitim oblicima takozvane privilegirane mobilnosti u čijim temeljima leži ista želja za samorealizacijom kroz prostornu promjenu: relokacija je ujedno i reorijentacija (Hoey, 2006). Skupina migranata životnog stila izrazito je raznolika - M. Benson i K. O'Reilly ponudile su okvir koji bi bio dovoljno širok da može povezati više raspršenih koncepata kao što su umirovljeničke migracije, migracije motivirane različitim prirodnim ili kulturnim ugodnostima te kontragradske migracije. Često se i povratne i bračne migracije promatraju kao oblik migracija životnog stila (Trundle, 2009), a taj prošireni pristup preuzeli smo i mi u ovom radu.

Ono što je dakle zajedničko navedenim različitim tipovima migranata jest doživljaj migracije kao puta u bolji i ispunjeniji (ili tek drugačiji) život. Migracija životnih stilova motivirana je potrebom da se realizira idealizirana vizija sebe, potencijalnog sebe, migracija je prema tome samorealizacijski projekt preslagivanja, re-kreiranja sebe u novom fizičkom i društvenom okolišu. Migracija je za ove pojedince iz razvijenijih dijelova svijeta »često antimoderan, samorealizacijski projekt, izlaz, potraga za neopipljivim boljim životom « (O’Reilly i Benson, 2009: 1). Bolji život ili ono što podrazumijevamo pod njim ima, naravno, mnogo oblika i nužno je riječ o subjektivnoj kategoriji, ali analizom veće količine empirijskog materijala autorice prepoznaju isti motivacijski obrazac, koji opisuju kao: bijeg od rizika, nesigurnosti, ispraznosti, brzoga životnog ritma, besmisla. Često se migracija dovodi u vezu s nekim prijelomnim životnim događajem (otkaz, rastava 
ili smrt supružnika) ili životnom etapom (umirovljenje i rađanje djece). Život poslije migracije prezentira se kao antiteza životu prije nje. Najvažnije osobine novih životnih stilova, tj. života poslije preseljenja, jesu pronalaženje ravnoteže između rada i slobodnog vremena, kvaliteta života i sloboda od prijašnjih ograničenja. Iako spominju i ekonomske razloge, migranti sebe ne prikazuju isključivo kao konzumente ili cost-benefit procjenitelje, već umjesto toga naglašavaju nematerijalne razloge za selidbu (Benson i O’Reilly, 2009b: 609-610). Potraga za boljim načinom života, iako je u osnovi ista kao i kod drugih tipova migranata, npr. izbjeglica ili tražitelja azila, ovdje označuje nešto drugo, upućuje na odabir određenog životnog stila, što je specifičan privilegij pojedinaca iz razvijenijih dijelova svijeta (Benson i O'Reilly, 2009b).

U akademskoj literaturi posvećenoj migracijama životnog stila posebno je značajno i pitanje odabira lokacije. Osim ugodne klime migranti životnog stila posebno vrednuju i autentičnost. Otuda i potreba za marginom, periferijom ili pak lokalnim manjim urbanim središtima ili zemljama koje su u nekim drugim povijesnim epohama imale posebno kulturno ili gospodarsko značenje, jer su upravo to prostori koje odlikuje izvornost. Često se bijeg traži i u ruralnome, kao pretpostavljenome kulturnom repozitoriju autentičnosti, zajednice i prirode (Hoey, 2009: 42). Osim ruralnih krajeva i pojedini kulturno-geografski lokaliteti poput Mediterana predmet su dekontekstualiziranih i generičkih, relativno nestvarnih predodžbi kao mjesta na kojima sunce uvijek sija i gdje je toplo, gdje se živi zdrav, opušten i romantičan život.

Također, za objašnjenje interesa za doseljavanje u hrvatske tradicionalne iseljeničke krajeve bitnim treba shvatiti i čin pristupanja Europskoj uniji, kojim je Hrvatska postala dio zajedničkog europskog prostora. Zajednički europski prostor karakteriziraju sloboda kretanja i prijenos različitih prava, što svakako na strukturnoj razini olakšava unutareuropske migracijske tokove. Naravno, osim nabrojenih globalnih čimbenika koji utječu na prostornu mobilnost postoje i brojne lokalne (korčulanske) posebnosti koje utječu na postojanje imigracije, a o čemu će biti riječi u sljedećem poglavlju.

\section{DOSELJENICI NA OTOK KORČULU -STUDIJA SLUČAJA}

Kao primjer studije slučaja odabrali smo otok Korčulu, i to iz više razloga. U prvom redu, postojala je bojazan da na malim otocima vjerojatno ne bismo naišli na značajniju brojnost pojave koju istražujemo (novodoseljeno stanovništvo). Stoga je bilo potrebno ograničiti se na veće otoke. Od većih 
je otoka njih nekoliko povezano mostom (Cres s Lošinjem te Krk i Pag s kopnom), te ih na neki način možemo smatrati i »pseudo" otocima. Stoga su nam iz grupe većih otoka preostali otoci Hvar, Brač i Korčula. Sva tri otoka do određene mjere prate sličnu povijesnu i socioekonomsku matricu, a između njih izabrali smo Korčulu, ponajprije jer je najnaseljenija.

Otok Korčula sa svojih petnaest i pol tisuća stanovnika drugi je po redu, gledano po broju stanovnika, hrvatski otok. Okružen je otocima Hvarom, Visom, Lastovom i Mljetom, a najbliži mu je poluotok Pelješac, od kojeg je na jednom dijelu udaljen tek nešto više od kilometra (slika 1).

\section{Slika 1. Otok Korčula}

Figure 1. The Island of Korčula

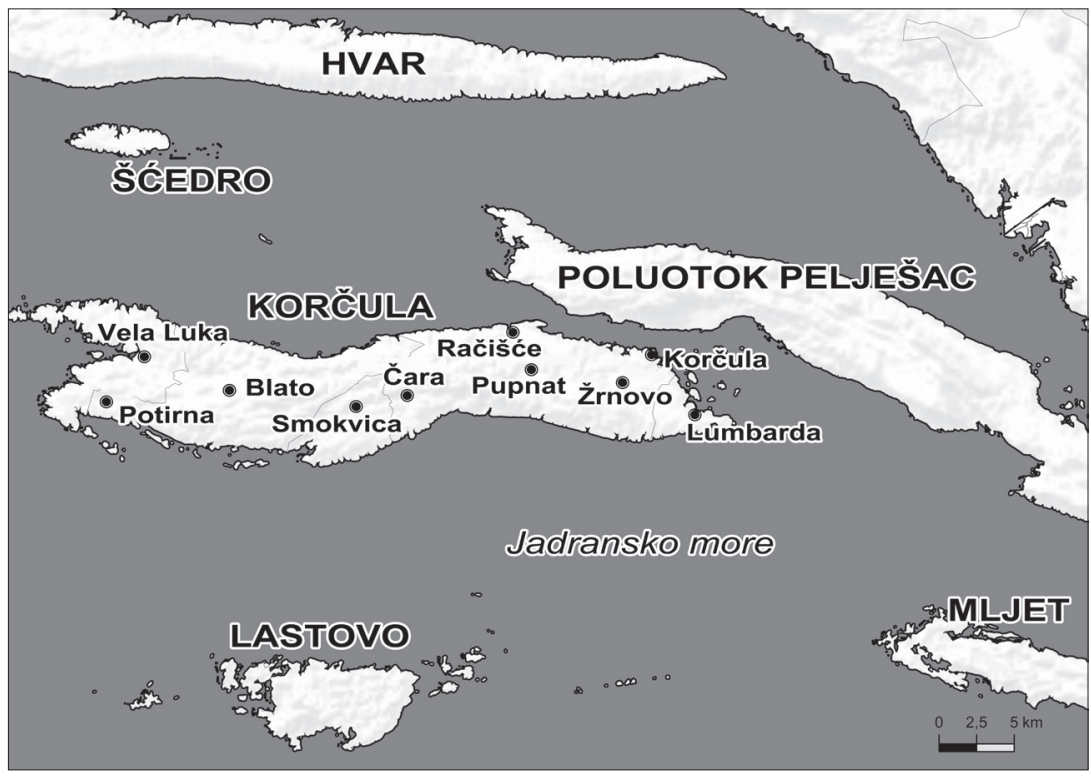

Izvori: Esri, DeLorme, USGS, NPS; Esri, USGS, NOAA

Podaci popisa iz 2011. pokazuju trend smanjenja stanovništva - na Korčuli je zabilježeno 660 stanovnika manje nego popisom 2001. (tablica 1). Dio gubitka možemo pripisati prirodnom padu stanovništva (483 više umrlih nego rođenih), a ostatak se odnosi na mehaničko kretanje stanovništva (177 više iseljenih nego useljenih) (Lajić i Mišetić, 2013: 188). ${ }^{2}$ Nastavak je to ne-

2 Prema popisu 2011., 69\% stanovništva Korčule od rođenja stanuje u istome mjestu (prema 52\% na razini Hrvatske), dok je 8,5\% doseljeno iz inozemstva (za cijelu Hrvatsku taj postotak iznosi 11,7\%), dakle niže od nacionalnog prosjeka (mala mobilnost i visoka razi- 
gativnih demografskih trendova koji su počeli puno prije (masovno iseljavanje s otoka počelo je krajem 19. stoljeća), a koji nisu karakteristični samo za otok Korčulu, već i za čitavi hrvatski otočni prostor s izuzetkom premoštenih otoka. Sve do kraja Drugoga svjetskog rata stanovništvo Korčule većinom se bavilo isključivo zemljoradnjom. Oni koji se nisu bavili isključivo zemljoradnjom bili su obrtnici - brodari, kamenoklesari, građevinari, krojači, postolari, stolari, brijači ili neke druge struke. Neki su plovili na domaćim ili stranim brodovima, a uz rad na polju mnogi su morali i ribariti kako bi se prehranili. Do otvaranja brodogradilišta Greben u Veloj Luci 1948., na čitavom otoku postojala je samo jedna tvornica. Bio je to manji pogon za preradu ribe osnovan 1892. (Cetinić, 1989; Mirošević, 2006; Mirošević, 2008: 177). $\mathrm{Na}$ otoku je nakon Drugoga svjetskog rata izgrađeno nekoliko tvornica - u prvom redu kako bi se spriječilo daljnje iseljavanje stanovništva. Do kraja osamdesetih zaposlenost otočana u industriji i proizvodnji te uslugama bila je dosta visoka - na otoku je radilo nekoliko tvornica, tri brodogradilišta, dvije brodarske tvrtke te više hotelsko-turističkih poduzeća i poljoprivrednih zadruga. Industrijaliziranost Korčule mogla se uspoređivati jedino s industrijalizacijom Krka (Stiperski, Malić i Kovačević, 2002). Crkvenčić i sur. (1984) zaključuju kako analiza razvoja industrije otoka upućuje na to da su se najviše razvile one grane koje su znale iskoristiti lokalne resurse: more i jeftinu radnu snagu - brodogradnja, prerada ribe te tvornice trikotaže, krede, limene ambalaže i elektronskih uređaja. Početak devedesetih donio je prelazak na tržišno gospodarstvo, te ne osobito uspješnu privatizaciju, koja se i odrazila na broj zaposlenih, koji je uvelike smanjen.

na endogamije). Doseljavanje iz inozemstva odnosi se većinom na Bosnu i Hercegovinu; slijede zemlje bivše Jugoslavije i ostale strane zemlje. Ipak, relativne vrijednosti koje su na Korčuli više nego u nacionalnom prosjeku tiču se dvojnog državljanstva. Ako pogledamo podatke o državljanstvu 2011. za otok Korčulu, možemo vidjeti kako 111 osoba popisanih kao stanovnici Korčule nema hrvatsko državljanstvo, a njih 659 (ili 4,72\%) ima dvostruko državljanstvo (hrvatsko i neko drugo). Usporedimo li te podatke s nacionalnim prosjekom od 1,98\% stanovništva koje uz hrvatsko ima neko drugo državljanstvo, vidjet ćemo da je postotak za otok Korčulu viši od prosjeka. Ako gledamo detaljnije navedene podatke o državljanstvu i doseljavanju, možemo primijetiti kako je najveći broj »stranaca « (osoba bez hrvatskog državljanstva) koncentriran u gradu Korčuli, dok u Smokvici nalazimo najveći postotak osoba s dvojnim državljanstvom (6,22\%) (Državni zavod za statistiku, 2015). 
Tablica 1. Broj stanovnika naselja otoka Korčule 1953. - 2011.

Table 1. Population of the Island of Korčula 1953-2011

\begin{tabular}{lrrrrrrr}
\hline & $\mathbf{1 9 5 3 .}$ & $\mathbf{1 9 6 1 .}$ & $\mathbf{1 9 7 1 .}$ & $\mathbf{1 9 8 1 .}$ & $\mathbf{1 9 9 1 .}$ & $\mathbf{2 0 0 1 .}$ & $\mathbf{2 0 1 1 .}$ \\
\hline Korčula & $\mathbf{2 4 1 4}$ & $\mathbf{2 4 5 8}$ & 2657 & 2953 & 3232 & 3126 & $\mathbf{2 8 5 6}$ \\
\hline Čara & 744 & 636 & 661 & 669 & 797 & 566 & 616 \\
\hline Pupnat & 758 & 691 & 772 & 512 & 488 & 433 & 391 \\
\hline Račišće & 1057 & 945 & 644 & 511 & 456 & 468 & 432 \\
\hline Žrnovo & 1501 & 1427 & 1363 & 1184 & 1267 & 1296 & 1368 \\
\hline Blato & 5676 & 5148 & 5912 & 3861 & 4093 & 3659 & 3570 \\
\hline Potirna & 111 & 68 & 25 & 13 & 14 & 21 & 23 \\
\hline Lumbarda & 1235 & 1142 & 1068 & 1040 & 1102 & 1221 & 1213 \\
\hline Smokvica & 1210 & 1137 & 1052 & 1002 & 1125 & 1012 & 916 \\
\hline Vela Luka & 4310 & 4297 & 4193 & 4398 & 4464 & 4380 & 4137 \\
\hline Ukupno & $\mathbf{1 9 . 0 1 6}$ & $\mathbf{1 7 . 9 4 9}$ & $\mathbf{1 8 . 3 4 7}$ & $\mathbf{1 6 . 1 4 3}$ & $\mathbf{1 7 . 0 3 8}$ & $\mathbf{1 6 . 1 8 2}$ & $\mathbf{1 5 . 5 2 2}$ \\
\hline
\end{tabular}

Izvor: Državni zavod za statistiku, Stanovništvo prema starosti i spolu po naseljima; Naselja i stanovništvo RH 1857.-2001.

Paralelo s iseljavanjem otok »uvozi« stanovništvo za potrebe lječilišnog turizma, a riječ je o visokoobrazovanim migrantima medicinskog profila. Još je nekoliko lokalnih posebnosti koje utječu na pojavu imigracije: gospodarska orijentacija na turizam i potreba dodatnog zapošljavanja u turističkoj sezoni, višedesetljetna tradicija zapošljavanja muškog dijela stanovništva na brodovima i s time povezana bračna migracija. Također, brojna emigracija prije i poslije Drugoga svjetskog rata odrazila se i na postojanje povratnoga migrantskog toka.

\section{METODOLOGIJA ISTRAŽIVANJA}

U istraživanju je primijenjen kvalitativni pristup. U prvom redu zato što je kao istraživački cilj bio postavljen zahtjev da se sazna što više o okolnostima doseljavanja na otok Korčulu, što je teže postići unaprijed definiranim anketnim upitnikom. Drugi razlog za odabir kvalitativne metodologije odnosio se na nedostatnost statističkog bilježenja migranata, što je problem koji je već davno uočen kako u međunarodnoj tako i u domaćoj statistici (npr. Castles i Miller, 2009; Mesić, 2002). Službena statistika bilježi samo registrirane promjene, minimalnog trajanja od godine dana, a populacija koja je nama $\mathrm{u}$ istraživanju bila relevantna potencijalno ima heterolokal- 
ne navike stanovanja (kombinira dvije ili više stambenih lokacija), tako da oslanjanje na službene podatke ne daje sasvim jasnu sliku. Osim toga ovim istraživanjem obuhvaćeno je nekoliko različitih statističkih i konceptualnih kategorija doseljenika - vanjskih i unutarnjih, trajnih i privremenih, koji se odvojeno bilježe, što je dodatno otežavalo pokušaj određivanja njihova broja i preciznog definiranja uzorka.

Kao glavna istraživačka metoda upotrijebljen je polustrukturirani intervju. Predložak za intervju sastojao se od sljedećih tema: život prije doseljenja na otok, neposredne okolnosti koje su dovele do preseljenja, proces selidbe i preseljenja, život na otoku i svakodnevne aktivnosti, odnos s lokalnom zajednicom, ocjena pojedinih usluga i sadržaja na otoku te planovi za budućnost. Namjera je istraživača bila obuhvatiti tri međusobno povezana aspekta migrantskog iskustva, a to su: život prije dolaska, odlučivanje i život nakon dolaska. ${ }^{3}$ Bitno je naglasiti kako ovo nije studija otočne zajednice, već pojave koju nalazimo na otoku. Također, u ovoj studiji nismo istraživali stavove lokalne populacije, već nam je fokus bio isključivo na novodoseljenom stanovništvu. U istraživanju je sudjelovalo 37 migranata, od čega njih trideset na otoku boravi cijelu godinu, a sedam na njemu boravi između šest i dvanaest mjeseci godišnje. Što se tiče prostornog razmještaja, najveći broj ispitanika u uzorku živi u Veloj Luci (sedamnaest); slijede Korčula (devet), Blato (četiri), Lumbarda (četiri), Smokvica (dva) i Pupnat (jedan). Najveći izazov istraživanju predstavljala je raznolikost ispitanika. Iako im je svima zajedničko do su se doselili na otok, kontekst njihova dolaska sasvim je različit. Kriteriji za odabir sugovornika bili su postavljeni relativno široko (nije bilo bitno je li riječ o doseljenicima iz drugih dijelova Hrvatske ili inozemstva, otočanima povratnicima ili radnim migrantima), a jedini čvrsto postavljeni uvjet bio je da na otoku borave dulje od šest mjeseci godišnje, odnosno da na otoku posjeduju dom. Drugim riječima, naš interes bio je usmjeren na domaće i strane useljenike koji većinu godine žive na otoku, odnosno kojima je otok mjesto stalnog boravka ili mjesto gdje borave većinu godine. Taj vremenski kriterij bio je uveden zato što su nas zanimali trajni(ji) posjetitelji otoka, s namjerom, kako u teorijskom tako i u empirijskom dijelu rada, odmicanja od privremenih posjetitelja otoka. Iako smo u uzorku pokušali prikupiti ispitanike iz svih mjesta na otoku, te što raznolikijih migrantskih putanja, napominjemo kako uzorak nije reprezentativan.

Izbjegavala su se pitanja koja bi na neki način uključivala vrijednosnu evaluaciju samog preseljenja, odnosno nije bio cilj da sudionici naknadno procjenjuju je li njihova odluka bila dobra ili loša, već su nas zanimali razlozi koji su vodili preseljenju, koja značenja sugovornici pridaju tome te kako je tekao sam proces preseljenja i navikavanja na novi život. 
Sugovornici su bili odabrani metodom snježne grude, preko sustava međusobnih preporuka. Intervjui su se provodili u tri etape tijekom 2013. i 2014., a odvijali su se najčešće u domovima sugovornika ili u javnim prostorima (kafići i plaža) i na radnome mjestu. Svi intervjui snimljeni su i transkribirani, a sugovornici su prije istraživanja dali svoj pristanak na sudjelovanje.

Uz polustrukturirani intervju sugovornici su ispunjavali i demografski anketni upitnik. Njegova svrha bila je osigurati osnovne sociodemografske podatke i podatke o osobnoj migracijskoj povijesti.

\section{TIPOLOGIJA DOSELJENIKA NA OTOK KORČULU}

Ukupno gledajući, uzorkom je obuhvaćeno 25 žena i 12 muškaraca. Prosječna dob ispitanika iznosila je 48,7 godina, pri čemu je najmlađa sugovornica imala 21 godinu, a najstariji sugovornik 75. Na otok su došli u rasponu od prije pola godine pa do šesnaest godina. Što se tiče bračnog statusa, velika većina ih je u braku ili izvanbračnoj zajednici (32). Ostali dio čine razvedeni/e, neudane/neoženjeni, udovci/ice. Tri četvrtine sugovornika migrirale su u paru, a ostali pojedinačno. Sugovornici žive u kućanstvima koja u prosjeku broje 2,86 članova. Nešto manje od polovine njih (šesnaest) ima djecu mlađu od osamnaest godina koja žive s njima u kućanstvu. Najveći udio sugovornika živi u vlastitoj kući (21), zatim u kući roditelja (deset) ili u unajmljenom stanu (šest).

Na temelju podataka iz intervjua i upitnika sugovornike smo grupirali u tri osnovne skupine prema njihovoj glavnoj vezi s otokom:

1. migranti povratnici (trinaest ispitanika)

2. bračni migranti/ice (dvanaest ispitanika)

3. doseljenici - bez prethodne bračne ili rodbinske veze s otokom (dvanaest ispitanika). ${ }^{4}$

Iako su te kategorije migranata analitički različite, u praksi (stvarnom životu) nailazimo i na njihova djelomična preklapanja. Na primjer ono što je počelo kao radna migracija nerijetko prerasta u bračnu. Stoga ovako razvrstane tipove migranata ne treba shvatiti kao zatvorene i potpuno nepovezane grupe. U nastavku ćemo za svaki od navedenih tipova reći nešto više o načinu dolaska na otok, podrijetlu i poslovima kojima se bave.

$4 \quad$ Podgorelec i Klempić Bogadi u svom istraživanju doseljenicima u pravom smislu riječi nazivaju samo one ispitanike koji su na otok došli »nevezano i uz kakve rodbinske veze « (2013: 41). Preuzeli smo njihov argument. 


\section{Migranti povratnici}

Ovu skupinu čine otočani (i/ili njihova djeca) koji su veći dio života proveli izvan otoka te su se na njega u određenoj životnoj fazi odlučili i vratiti. Ovdje su nas zainteresirali razlozi njihova povratka, posebno ako znamo da je riječ o populaciji koja se iz iste zajednice jednom iselila. Unutar skupine povratnika možemo razlikovati dvije podskupine: povratnici prve generacije i povratnici druge generacije. ${ }^{5}$ Povratnici prve generacije većinom su migrirali u paru, imaju odraslu djecu, završenu srednju školu i u mirovini su. Povratnici druge generacije ${ }^{6}$ (rođeni ili odgojeni u zemlji dolaska svojih roditelja) vraćaju se u radno aktivnoj dobi, s malom djecom, i imaju viši stupanj završene škole. Zanimljivo je da polovina povratnika druge generacije u uzorku ovog istraživanja ima samo jednog roditelja rodom s Korčule, dok se po podrijetlu drugog roditelja razlikuju. I. Lajić (1992: 294) upravo povratne migrante vidi kao idealne doseljenike na otočni prostor, i to u prvom redu zbog »teške adaptacije neotočnog stanovništva na specifični, tradicionalnokonzervativni otočki način života«. »Otočanin-povratnik « poznaje otočni životni stil te prolazi lakšu psihološku, društvenu, klimatološku, etničku i drugu adaptaciju. Napominje kako suvremeni problemi gradskog života (nezaposlenost, stambena kriza i ekološki problemi) nagovještaju mogućnost reverzibilnih migracija već u bližoj budućnosti, i to ne samo stanovništva u umirovljeničkoj dobi (Lajić, 1992: 294). Iako je istina da je bivšim otočanima otočni život poznat i blizak, to ne znači da su njihov dolazak (tj. povratak) i ostanak na otoku vjerojatniji nego kod drugih kategorija migranata. J. Čapo Žmegač piše kako su »novija istraživanja ustanovila da povratak nije nedvosmislen i jednostavan te su razvila temu njegove ambivalentnosti, i u prvoj i u kasnijim generacijama migranata povratnika « (2010: 14-15).

Često se naglašava kako su migracije vezane uz prijelomne životne trenutke kao što su vjenčanje, proširenje obitelji, rastava ili umirovljenje (npr.

Kako detaljniji pregled teorija o povratnim migracijama izlazi iz okvira ovog rada, nećemo ih ovdje navoditi, a čitatelja upućujemo na rad K. Peračkovića (2001).

6 Za diskusiju o nazivima i definicijama druge generacije vidjeti Vathi (2011: 105). Pod drugom generacijom najčešće podrazumijevamo djecu imigranata koja su rođena u zemlji dolaska ili djecu imigranata koja su u zemlju dolaska došla u dobi do polaska u osnovnu školu. Pojedina istraživanja pokušala su preciznije definirati drugu generaciju, tako da su se pojavili termini poput 1,75., 1,5., i 1,25. generacija (Rumbaut, 1997, prema Vathi, 2011: 106), a koji se odnose na djecu koja su u vrijeme imigracije bila mlađa od šest godina, između šest i dvanaest godina, odnosno starija od dvanaest godina. U upotrebi je i termin druga i pol generacija (2,5. generacija) (Casacchia i Natale, 2007, prema Vathi, 2011: 106) koji se odnosi na djecu iz miješanih brakova. 
Boyle, Halfacree i Robinson, 1998; Božić, 2001). ${ }^{7}$ U slučaju povratnih migracija prve generacije na Korčulu umirovljenje se pokazuje kao jedan takav značajan prijelaz. Sugovornici u istraživanju s Korčule su emigrirali između šezdesetih i osamdesetih godina 20. stoljeća, i to u Australiju, Kanadu, SAD, Republiku Južnu Afriku ili u veće gradove u Hrvatskoj. Napustili su otok u svojim ranim dvadesetim godinama i najčešće već bili oženjeni/udane za otočanku/otočanina. Veze sa zavičajem održavali su redovitim ili povremenim dolascima tijekom ljetnih ili nekih drugih praznika. Korčulu su posjećivali većinom kako bi vidjeli rodbinu (posebno starije roditelje) i poznanike, iako nijedan povratnik prve generacije nije izjavio da se vratio zbog obiteljskih razloga. Razlozi za povratak, kako ih navode migranti povratnici prve generacije u ovom istraživanju, subjektivni su i povezani su s osjećajem pripadnosti otoku, nostalgijom, ali i posve praktični i objektivni - održavanje aktivnosti nakon dolaska u mirovinu, istek dozvole boravka i osiguravanje ugodne budućnosti kroz povratak s ušteđevinom. Ostanak nakon umirovljenja u stranoj zemlji još se uvijek smatra upitnim. Uobičajeno je kako u znanstvenim radovima tako i u popularnom diskursu radne migracije smatrati okončanim dosezanjem dobi za mirovinu, te se $u$ toj fazi predmnijeva povratak. Taj očekivani povratak u kasnijoj životnoj dobi osporavaju mnoga novija istraživanja te se primjećuje kako migranti ostaju u zemlji u kojoj su proveli čitavi radni vijek ili barem njegov veći dio ili kombiniraju život na više lokacija zbog raznih administrativnih, zdravstvenih, ali i obiteljskih razloga (npr. Bolzman, Fibbi i Vial, 2006; Hunter, 2011). Logično je onda pitanje kako to da su se sugovornici u ovom istraživanju vratili kada se većina njihovih suotočana emigranata ne odlučuje na povratak. Ono što se odmah primjećuje jest da gotovo svi povratnici prve generacije obuhvaćeni istraživanjem imaju bračne partnere koji su s Korčule, te su se vratili zajedno na otok. Udaljene obiteljske i prijateljske veze održavaju uglavnom telefonom, manje Skypeom. Održavanje bliskih odnosa s djecom i unucima predstavlja im najveći izazov. Njihova identifikacija s Korčulom vrlo je jaka, iako ih njihovo iseljeničko iskustvo čini različitima od ostatka lokalne zajednice. Povratnici u starijoj životnoj dobi druže se najviše međusobno, sa susjedima ili rođacima i manje inzistiraju na novim prijateljstvima. Ipak, jednom kada je do povratka došlo, on je vrlo vjerojatno trajan. Iako se sve više naglašava (posebice u okviru transnacionalne istraživačke perspektive) mogućnost da kroz kretanja između zemlje dolaska i zemlje primitka (ili neke treće ze-

Ovoj listi možemo pridodati i smrt. Neka su istraživanja zabilježila veliku želju migranata da se njihovo tijelo vrati, tj. pokopa doma, jer su ih starenje i bolest »zatekli« u zemlji kojoj ne osjećaju pripadnost (Gardner, 2002; Hunter, 2011). 
mlje) migranti održavaju društvene, ekonomske, poslovne i obiteljske veze na više lokacija, odgovori povratnika prve generacije na otoku Korčuli ne podržavaju u potpunosti te pretpostavke. Tome pridonose i neki sasvim praktični financijski razlozi - naime zbog mogućih poreznih komplikacija povratnici se najčešće odlučuju na prodaju nekretnina u zemljama u kojima su živjeli. To i simbolično označuje kraj njihova boravka u zemlji odseljenja i orijentaciju na novi dom u Hrvatskoj. Također, ta akumulacija kapitala, uz »strane« mirovine, najčešće im omogućuje relativno ugodan život.

Povratnici druge generacije u uzorku dolaze iz različitih zemalja: Republike Južne Afrike, Njemačke, SAD-a, Kanade i Australije, a jedan je ispitanik iz Hrvatske. Tijekom života u drugim zemljama svi su redovito posjećivali otok, a njihovi su doživljaji otočnog života ocijenjeni vrlo pozitivno, povezano s djetinjstvom i mladošću, s odmorom, slobodom i zabavom, što se vidi i iz izjave povratnika druge generacije rođenog i odraslog u Kanadi: 8

Ja sam uvijek zna, doša sam ode proi put u životu, um, bilo je rano $u$ šestdeset i peta $i$ ja sam se, I fell in love with here $i$ to je to [...] I onda sam ovako svaku godinu, svaku drugu godinu sam svratio ovde, ali onda mi je bilo ovako fun, adventure, romance $i$ to sve. (Intervju br. 3, M, 65)

R. King i A. Christou (2010) pišu o povratnicima druge generacije kao o »kontradijasporičnoj migraciji«, odnosno kao o povratku raspršenoga iseljenog stanovništva. Povratak druge generacije smatraju sve značajnijim fenomenom specifičnim upravo za one dijaspore koje su nastale kao posljedica radnih migracija ili izbjeglištva u prošlih pola stoljeća. Isti autori zaključuju kako je potraga za pripadanjem i domom za drugu generaciju vrlo snažno i emocionalno iskustvo koje može utjecati na tijek života. Prema njima, povratnici izriču nostalgiju za zamišljenom stabilnošću i smislenošću prošlih vremena i mjesta (King i Christou, 2010).

Razlozi za povratak druge generacije migranata različito su artikulirani - od »uvijek mi je bila želja vratiti se« do veće fizičke sigurnosti koju nudi otok, ali ono što ih povezuje jest obiteljska ukorijenjenost razloga za povratak. Obiteljski uvjetovani razlozi za povratak pripadnika druge generacije strukturirani su ili oko a) povratka s roditeljima kao dugo željeni grupni čin cjelokupne šire obitelji, b) povratka zbog obveze prema starijim roditeljima i c) povratka zbog želje da se vlastitoj djeci omogući sigurno i bezbrižno odrastanje. Otočna sredina za mnoge povratnike iz većih svjetskih gradova uistinu izgleda kao raj - idealno mjesto za odrastanje, a posebno ako život u

Ispitanik u intervjuu kombinira hrvatski i engleski jezik. Kao pripadniku druge generacije hrvatskih emigranata u Kanadi bliži mu je engleski jezik. Jezične pogreške nismo ispravljali. 
manjemu mjestu omogućuje bolju ravnotežu između poslovnih i obiteljskih obaveza:

Ali smo uvik planirali doć nazad, jer jednostavno, ne znam, tamo sam živija, ali smatra sam da tamo se radi, ovde se živi. Kad gledaš cjelokupni život, tamo je stvarno, ono ujutro si se diga, oša si na posa i doša si doma na večeru. (Intervju br. 10, M, 43)

Odluka da se započne život negdje drugdje događa se u kontekstu pitanja o tome što život čini vrijednim življenja - za ove migrante odabir gdje će se živjeti također je i odabir kako će se živjeti, te nije riječ samo o ekonomskoj odluci, već i moralno-vrijednosnoj (usp. Hoey, 2006: 347).

Povratni migranti pokazuju se kao migranti koji dugo planiraju povratak i čekaju za to povoljan trenutak. U odlučivanju o migraciji obitelji dob djeteta jedan je od ključnih faktora koji se uzima u obzir (Ryan i Sales, 2013). Često se taj trenutak povezuje s djetetovom dobi i obrazovnom fazom (polazak u osnovnu ili srednju školu i odlazak na fakultet). Također, povratak se nekad povezuje i s otvorenom poslovnom mogućnošću na otoku. Karakteristično za ovu grupu povratnih migranata jest da najčešće posjeduje obiteljsku kuću na Korčuli, pa riješeno stambeno pitanje u velikoj mjeri olakšava njihovu odluku o povratku. Za razliku od povratnika prve generacije, u zemlji iz koje su došli nerijetko ostavljaju kuću, koju iznajmljuju - u isto vrijeme to im je svojevrsna odstupnica koja im, u prvom redu, osigurava određeni stalni pritok novca, a s druge strane sebi ostavljaju otvorenom mogućnost za povratak.

\section{Bračna migracija}

Kako se pokazalo terenskim istraživanjem, bračna migracija na otoku Korčuli većinom se odnosi na žene, dakle većinom je riječ o bračnim migranticama. Posljedica je to prevladavajuće virilokalne prakse na otoku prema kojoj se žene nakon udaje/započinjanja veze doseljavaju u muževljevo kućanstvo. Geografsko podrijetlo bračnih migrantica na Korčuli, odnosno nacionalna pripadnost, vrlo je različito i istraživanjem nije utvrđena prisutnost više doseljenica istog podrijetla, odnosno nije posrijedi organizirano ili posredovano upoznavanje. Bračne migrantice spominju se i u drugim istraživanjima hrvatskih otočnih doseljenika (Podgorelec i Klempić Bogadi, 2013: 42-51) te nisu korčulanska specifičnost. Prisutnost te migrantske skupine možemo objasniti činjenicom da se značajni broj Korčulana zapošljava 
na brodovima, ${ }^{9}$ što otvara mogućnost započinjanja međunarodnih emotivnih i/ili bračnih veza:

On i ja smo radili na kruzeru. [...] Tako smo se upoznali, na kruzeru. Onda on me pozvao jedanputa ovdje u Hrvatsku, ja sam došla krajem ljeta i bilo je super, oduševilo me. (Intervju br. 8, Ž, 42)

Osim toga pojavu bračnih migrantica potaknulo je i već spomenuto iseljavanje muškaraca s Korčule. Nakon što su odlučili okončati svoj višegodišnji boravak izvan otoka, odnosno izvan Hrvatske, povratak je često značio dolazak sa suprugom »strankinjom « ${ }^{10} \mathrm{U}$ niže navedenom citatu iz intervjua ispitanica je došla iz Australije, a suprug je rodom iz Korčule:

Glavni razlog [za dolazak na otok] je bio moj suprug. Otišao je kada mu je bilo 15 godina... Uvijek se želio vratiti natrag. Vrlo je sentimentalan prema ovom kraju i činjenici da su njegov otac i njegov pra-pradjed živjeli ovdje i bili kršteni u crkvi u kojoj je on kršten. (Intervju br. 23, Ž, 63)

Jednako govori i ovaj primjer ispitanice iz Kanade udane za Korčulanina rođenog u Kanadi:

Bili smo zajedno jedno kratko vrijeme, kada me pitao bi li, ako ikada bude nešto ozbiljnije između nas, razmislila o tome da se s njim preselim na Korčulu. (Intervju br. 3, Ž, 62)

Također, upoznavanje odnosno međunarodna ljubavna veza u nekoliko slučajeva započeli su turističkim posjetom otoku:

... ja sam svako ljeto dolazila tu na odmor na par tjedana, i prije pet godina, ustvari šest godina sam došla isto na odmor $i$ upoznala svoga muža. Klasična priča. I kako je on, on je iša mene posjetiti u Južnoj Africi, ali je rekao da, da ne postoji šansa da će on poć tamo živjet tako da sam se morala odlučit $i$ ja sam došla ovdje. (Intervju br. 20, Ž, 42)

Unutar skupine bračnih migrantica možemo razlikovati tri podskupine: a) supruge pomoraca, b) supruge povratnika i c) supruge turistice (skupina koja je supruga upoznala tijekom turističkog posjeta otoku). Osnovna je razlika među njima u tome da se jedne sele sa supružnikom, dok druge migriraju da bi se pridružile supružniku (Santacreu, Baldoni i Albert, 2009: 57). Namjerno ne upotrebljavamo riječ "partnerice" jer je ovdje gotovo u svim slučajevima riječ o suprugama. Naime formalno ozakonjenje veze bilo

9 I. Lajić (1992: 149) navodi podatak kako je između 1947. i 1965. samo na domaćim brodovima bilo zaposleno 1109 pomoraca s otoka Korčule.

10 Pomorci i iseljenici dosta su pridonijeli trendu egzotizacije otoka, tako da snahe Južnoamerikanke, Azijke i Australke već tridesetak godina na otoku nisu novost. 
je nužno da bi doseljenice (koje su najčešće druge nacionalnosti) mogle zadovoljiti zakonske uvjete boravka. ${ }^{11}$

Podaci o stupnju obrazovanja/stručnoj spremi bračnih migrantica pokazuju kako više od pola ispitanica u uzorku ima sveučilišno obrazovanje, četiri su nezaposlene, pet ih je zaposleno ili samozaposleno, a tri su u mirovini. Iako ih je otprilike polovina $\mathrm{u}$ radno aktivnoj dobi i zaposlena, često njihova znanja i diplome stečene u inozemstvu nisu adekvatno iskorišteni i vrednovani. Nerijetko i same bračne migrantice, zauzete brigom za malodobnu djecu i kućanstvo, ne traže aktivno posao. Pet od dvanaest bračnih migrantica ne zna hrvatski ili ga zna »samo malo«. ${ }^{12}$ Značenje poznavanja jezika u procesu migracije nije svedeno samo na komunikacijski aspekt. Jezik - bilo materinji, bilo jezik zemlje dolaska, u procesu migracije osim komunikacijskog značenja može imati i identitetsko, integracijsko, statusno te političko značenje. Ispitanice koje znaju hrvatski jezik (a kojima nije bio materinji) naučile su ga ili na suprugovu intervenciju ili uz pomoć članova suprugove obitelji, najčešće svekrve (stariji članovi obitelji često ne znaju engleski, tako da je učenje hrvatskoga bio jedini mogući način sporazumijevanja). Bračne migrantice koje su majke mlađe djece inzistiraju na dvojezičnosti kod kuće, čime se osigurava povezanost s majčinom obitelji, ali i, prema riječima nekih sugovornica, poslije djeci omogućuje da odaberu studij u nekoj drugoj zemlji, ili se eventualno vrate u majčinu domovinu:

Želim tamo zadržati svoju kuću u slučaju da bilo što ode krivim putem, i bilo bi lijepo kada bi obje [misli na svoje kćeri] mogle tamo studirati. (Intervju br. $13, \check{Z}, 43)$

Udaljenost od obitelji, nepoznavanje jezika, nemanje državljanstva i status nezaposlenosti stavlja bračne migrantice $u$ potencijalno nepovoljnu situaciju i čini ih ranjivom skupinom (vidi npr. Merali, 2008; Trundle, 2009; Charsley, 2014). Položaj žena pomoraca dodatno je otežan jer su veći dio godine same, okružene suprugovim rođacima, prepuštena im je većina brige oko djece i kućanstva te se u manjim zajednicama pomno prati svaki njihov korak, odnosno sve njihove aktivnosti izvan kuće. Takav tip socijalne kontrole (rodbine i susjedstva) posebno teško prihvaćaju sugovornice koje su živjele u velikim urbanim središtima, u kojima je stupanj privatnosti znatno

11 Stav službene vlasti vezana uz bračnu migraciju varira među državama. K. Charsley (2014) navodi kako zemlje Južne Europe uobičajeno gledaju pozitivno na spajanje obitelji, kao nešto što bi moglo olakšati integraciju migranata, dok se u zemljama Sjeverne Europe obiteljska migracija vidi kao neželjeni nusprodukt prijašnje radne migracije.

12 »Samo malo« njihova je subjektivna procjena znanja hrvatskog jezika, a to uključuje poznavanje najčešćih svakodnevnih izraza dovoljnih za uspješno sporazumijevanje u trgovini i kafiću. 
viši. Usprkos svemu tome preseljenje, odvajanje od vlastite/roditeljske obitelji i prijatelja te napuštanje dotadašnjeg posla opravdavaju se emocionalnim razlozima - ljubavlju. Neki istraživači zagovaraju svojevrsni »emotivni okret « u istraživanju migracija te tvrde kako je ljubav, odnosno afekti često u samom »srcu migrantskog odlučivanja« (Mai i King, 2009: 296). Autori tvrde da ljubavna motivacija do sada nije $u$ istraživanjima migracija dobila važnost koju zaslužuje iako se u društvenim znanostima sve veća uloga pridaje emocijama u objašnjavanju "ponašanja ljudi u prostoru «. Ljubavni migranti pojavljuju se kao sve značajniji i prisutniji tip migranata (King, 2009). Mišljenja smo da emocije (u ovom slučaju zaljubljenost, ljubav) uistinu igraju značajnu ulogu pri donošenju odluke o seljenju, međutim, kao što se pokazalo $\mathrm{u}$ ovom istraživanju, pregovori partnera u vezi s odabirom zajedničkog mjesta stanovanja počivaju i na vrlo praktičnim razlozima kao što su mogućnost pronalaženja posla, dobivanja radnih i boravišnih dozvola, posjedovanja nekretnine, nižih troškova stanovanja, sigurnosti djece i sl. Također, odluka o mjestu stanovanja predmet je i kompromisa, pa tako i bračne migrantice u različitim životnim fazama mijenjaju zemlje nastanjenja - $\mathrm{u}$ jednoj fazi žive u svojoj domovini, zatim u suprugovoj, pri čemu izmjenjivanje može biti jednokratno, ali i višekratno. Mnoge od njih imaju zanimljive ideje za pokretanje nekih aktivnosti koje bi poboljšale kvalitetu života otočne zajednice. Ipak, tek rijetke uspiju pokrenuti zamišljeni posao (npr. tečaj aerobika) jer su u komunikaciji najčešće ograničene na ženske prijateljice koje su se isto kao i one doselile na otok, bez značajnije podrške lokalne samouprave, ili ih pak njihovo nepotpuno znanje hrvatskog jezika sprečava u nastojanjima. Potencijal bračnih migrantica kao akterica društvenih promjena na otoku (Burgess, 2004) još nije dokraja iskorišten, iako već i sama njihova prisutnost u lokalnoj zajednici na neki način »otvara" zajednicu za drugačije, nove ideje.

\section{Doseljenici}

U treću kategoriju dolaznih migranata na otok Korčulu svrstali smo doseljenike, a riječ je o svima onima koji su na otok došli nevezano uz bilo kakve rodbinske veze. Prema dobi, posrijedi su doseljenici između 31 i 67 godina, među kojima je troje u mirovini, dok su ostali radno aktivni. $\mathrm{S}$ obzirom na zemlju iz koje su se doselili, dvoje ispitanika došlo je iz Hrvatske, dvoje iz Bosne i Hercegovine, a šestero iz Velike Britanije i SAD-a. U ovoj skupini najviše je ispitanika samozaposleno. Već je spomenuto kako otok »uvozi« usko profilirane radnike poput zdravstvenih, ali doseljenike na otok privlači i relativno neiskorišten turistički potencijal otoka (npr. nekoli- 
ko ronilačkih klubova na Korčuli u vlasništvu je doseljenika, kao i agencija za promet nekretnina i nekoliko specijaliziranih turističkih agencija). Iz ove kategorije možemo izlučiti dva moguća načina povezanosti migracije i posla kojim se doseljenici bave. Prvu skupinu čine doseljenici koji rade poslove koje je moguće obavljati na daljinu, poput nekih umjetničkih zanimanja, konzultantskog ili prevoditeljskog posla. Drugu skupinu čine doseljenici koji su se prilagodili lokalnim potrebama i specifičnostima. U njihovu slučaju preseljenje najčešće predstavlja prekid s prijašnjim poslovima, a ako ne potpuno, onda barem u pogledu nastavka rada s puno manje opterećenja i/ ili puno više zadovoljstva. Tu kategoriju doseljenika moguće je povezati i s migracijama životnog stila.

Prvo pitanje koje smo postavili sugovornicima doseljenicima bilo je zašto su se odlučili baš za Korčulu. Iz odgovora nekih sugovornika jasno je da im je živjeti u Dalmaciji bila dugogodišnja želja.

Godinama prije kad smo mi iz kontinenta [...] išli na more [...] jedno 15, 16 kilometara prije mora, prije obale zapuhne me onaj miris. Kad dođem ovdje, miris borovine, oni curčci, to je ostavilo traga, to nam je bila hrana nama kontinentalcima narednih sedam-osam mjeseci. To kad godinama tako traje, 20, 30 godina, onda to najedanput eksplodira. (Intervju broj 29, M, 66)

Gore spomenuti ispitanik na Korčulu je došao prije šest godina iz Bosne i Hercegovine. Slično kao i ostali pripadnici skupine migranata životnog stila opisuje kako je dugo želio preseliti se »negdje na more«. Objašnjava da je slučajnost što je na kraju odluka bila baš Korčula, ali da je dugo postojala »latentna želja da na kraju krajeva budemo negdje tu «. O dugogodišnjoj prikrivenoj želji da se preseli na neko drugo mjesto govori i supruga drugog doseljenika:

Tom, kao pravi Nizozemac, iz nekog čudnog razloga nije više želio živjeti u Nizozemskoj. Stalno je tražio neko drugo mjesto i onda, slučajno, dogodilo se da je to Korčula. (Intervju br. 4, Ž, 55)

Sugovornica objašnjava kako prije njihova turističkog putovanja na Korčulu suprug nikada nije bio u Hrvatskoj. Korčula je prvo mjesto koje je posjetio, oduševio se, i iste godine kupili su poluporušenu kuću u samom središtu grada. Odluka je bila impulzivna, ali samo zato što su idealno mjesto tražili godinama. »Idealna lokacija « zapravo postoji kao više ili manje jasna slika u glavi, a kroz putovanja događa se svojevrsna rezonanca zamišljenoga i realnoga. Iako istraživanja u maniri migracija životnih stilova često naglašavaju kako ispitanici odabiru ruralne lokacije baš kao protutežu gradskim lokacijama, sama Korčula primjer je pozitivnoga, neiskvarenoga 
povijesnoga grada, urbane idile. Ali potraga za novom destinacijom očito je refleksija jedne dublje potrage:

Jednostavno htjeli smo promijeniti naš [misli na suprugu i sebe] život, nismo bili zadovoljni s vlastitim životnim stilom. Nismo uživali u poslu, radili smo dugo. Nemate vremena uživati u životu. Jednostavno smo shvatili da život u Velikoj Britaniji onako kako su svi navikli tamo živjeti nije za nas. Htjeli smo nešto laganije u čemu ćemo moći uživati. (Intervju br. 18, M, 34)

Sugovornik navodi kako mu je, nakon što bi većinu dana proveo na poslu ili na putovanju od doma do posla i natrag, dnevno ostajalo dva i pol sata za prehranu i odmor. »Nije to bio baš neki život«, zaključuje. Ušteđevina i prihodi od vlastite manje tvrtke, u kombinaciji sa životnim troškovima koji su na Korčuli puno niži nego u Londonu, omogućuju im znatno uravnoteženiji i opušteniji život.

Osim usporedbe s Italijom, jedan ispitanik Korčulu je usporedio s drugom poznatom turističkom destinacijom - Mallorcom, i to kakva je bila prije trideset godina:

Jedan od razloga zašto mi se sviđa ovdje je zato što je Mallorca bila ovakva prije 30 godina i možda je to i podsvjesno. [...] Korčula i Mallorca su vrlo slične, ali Mallorca se u zadnjih 15-ak godina jako izgradila. Ovdje primjećujem sve one prirodne ljepote koje na neki način tamo nestaju. (Intervju broj 17, M, 48)

Kao razlog svog dolaska na Korčulu par umirovljenika navodi želju da se odmaknu od američkoga potrošačkog društva i vrijednosti koje se u toj zemlji promoviraju. Oboje je prethodno bilo zaposleno u propulzivnim američkim sektorima gospodarstva - on u financijskome, a ona u poslu s nekretninama. Iako su već bili u dobi kada mogu ići u mirovinu, i dalje su naporno radili jer su imali privatne tvrtke. U početku su na otoku samo kupili ruševnu kuću, ali ne s namjerom da se u njoj trajnije nasele. Hrvatsku su izabrali zato što su suprugovi djed i baka podrijetlom iz okolice Karlovca. Putovali su tim dijelom Hrvatske i otok im se svidio jer »nije bila prevelika gužva«. Njihova želja da malo uspore poklopila se s velikom krizom dvaju sektora u kojima su radili. U jednom trenutku sva njihova financijska ulaganja u nekretnine činila su se propalima. Oporavili su se, ali su definitivno odlučili preseliti se na otok. Ističu kako su kuću sami preuređivali. U kući ne žele imati ni televizor, već im je cilj živjeti jednostavnim životom, izbjegavajući svaki »nepotreban stres«. 


\section{ZAKLJUČAK}

Cilj ovog rada bio je istražiti populaciju novijih trajnih doseljenika na otok Korčulu. Željeli smo dobiti uvid u razloge doseljavanja u područja iz kojih se stanovništvo u većoj mjeri iseljava. Iako brojčano nije riječ o značajnijemu doseljeničkom valu, njegovo postojanje ne treba se zanemariti. Skupina novih otočnih doseljenika razlikuje se dobno, nacionalno i socioekonomski, a za potrebe ovog istraživanja podijeli smo ih u tri kategorije na temelju njihove prethodne (ne)povezanosti s otokom: povratnici, bračni migranti i doseljenici. Povratnici su i u prethodnim istraživanjima prepoznati kao najčešća imigrantska skupina na hrvatskim otocima, što se potvrđuje i u ovom istraživanju. U skupini povratnika riječ je o otočanima (ili njihovoj djeci i potomcima) koji su veći dio života proveli izvan otoka. Najveći dio vratio se iz prekooceanskih zemalja i Europe, dok je nešto manji dio došao iz drugih dijelova Hrvatske. Osim povratnika prve generacije, koji većinom dolaze nakon umirovljenja, nalazimo i povratnike druge generacije, koji se vraćaju u radno aktivnoj dobi. Možemo zaključiti kako je za povratnike prve generacije dolazak na otok povezan najčešće s umirovljenjem, nisu zainteresirani za traženje plaćenog posla, ekonomske prilike na otoku ne utječu na njihov socioekonomski status te im akumulirana ušteđevina ili »strana« mirovina omogućuje ugodan, iako ne luksuzan život. Njihov povratak na otok znači i potragu za novim dnevnim sadržajima koji bi mogli zamijeniti prijašnji odlazak na posao te se vraćaju tradicionalnim djelatnostima: maslinarstvu, vinarstvu i poljoprivredi bez komercijalizacije - samo za vlastite potrebe.

U ovom istraživanju prepoznati su i povratnici druge generacije. Visoko su obrazovani i uglavnom se doseljavaju s djecom (mlađom od osamnaest godina). Većinom su zaposleni ili samozaposleni s brojnim inicijativama za poboljšanje uvjeta otočnog života i aktivno su angažirani u lokalnoj zajednici pa stoga povratnici druge generacije predstavljaju značajni društveni i demografski resurs za manje otočne zajednice. Iako je baza potencijalnih povratnika u tradicionalno iseljenička područja velika, ipak nije realno očekivati da će oni unijeti željenu demografsku dinamiku u otočnu zajednicu. Naime za povratak se još uvijek odlučuje relativno mali broj iseljenika, a u slučaju otoka Korčule olakšavajuća je okolnost ta što je otok relativno velik te ima dobro organiziranu zdravstvenu skrb i veći broj državnih institucija (osnovne i srednje škole, katastar, sud i urede javne uprave).

Kao drugu zasebnu skupinu izdvojili smo bračne migrantice koje su se na otok doselile sa suprugom otočaninom ili zbog udaje za otočanina/veze 
s otočaninom. U našem istraživanju to je ujedno i najmlađa skupina u uzorku. Kako se često ističe činjenica niskoga otočnog fertililteta koji je rezultat smanjene baze stanovništva reproduktivne dobi, dokaz o prisutnosti i voljnosti mlađega ženskog stanovništva da se preseli na veći otok poput Korčule, slično kao i kod povratnika druge generacije, govori u prilog tezi o mogućemu (iako skromnom) revitalizirajućem potencijalu doseljenika, te može biti jedna od točaka u nekoj strategiji poticanja doseljavanja na otoke.

Kao treću zasebnu skupinu možemo izdvojiti doseljenike, odnosno one koji su na otok došli nevezano s rodbinskim vezama. Neke od njih privukla je poslovna prilika, dok je put dolaska na otok za druge bio vođen inicijalnim turističkim posjetom koji je prerastao u trajniju povezanost. Ovaj nalaz dokazuje kako (barem na većemu hrvatskom otoku kao što je Korčula) pojedine gospodarske aktivnosti (u prvom redu turizam i zdravstveni turizam, zatim trgovina) imaju snagu privlačenja novog stanovništva koliko god se ponavljala tvrdnja o skromnosti i nerazvijenosti otočnih ekonomija.

Iskustvo života u drugoj zemlji sugovornike dvojako određuje - s jedne strane primjećuju brojne prednosti života u manjim zajednicama, posebno u pogledu sigurnosti i mogućnosti postizanja bolje ravnoteže između slobodnog vremena i posla, a s druge strane upravo ta sveprisutna familijarnost ponekad djeluje ograničavajuće.

Posebni naglasak u radu dan je teoriji migracija životnih stilova izravno je povezujući s navedenim tipovima migranata. No, u tom povezivanju nameću se dva nova pitanja. Prvo se tiče odnosa migracija životnog stila kao teorije koja naglašava idealističke, gotovo utopijske razloge preseljenja i sasvim praktičnih i instrumentalnih razloga preseljenja u tradicionalno iseljenička područja koje navode pojedini migranti u ovom istraživanju. Drugo pitanje, tj. poticaj za daljnje promišljanje, tiče se značenja ekonomskih čimbenika u donošenju konačne odluke o preseljenju. Fokus na neekonomski motiviranim migracijama ili, bolje rečeno, na migracijama koje nisu motivirane isključivo poslom i zaradom, ne znači da u onome što nazivamo »novi motivi i oblici migracija« ekonomski faktori nemaju utjecaja, već da oni jednostavno nisu dominantni ili da se prepleću s drugim skupinama motiva poput povećanja kvalitete života te smirenijeg i opuštenijeg načina života. Naravno, ekonomska racionalnost u slučaju migranata životnog stila ne može se potpuno negirati s obzirom na to da je život na otoku (iako skuplji nego u drugim dijelovima Hrvatske) još uvijek jeftiniji od života u većini drugih europskih zemalja.

Na temelju primjera Korčule možemo zaključiti kako su veći hrvatski otoci, usprkos negativnim demografskim trendovima, potencijalno pri- 
vlačne destinacije za određeni broj domaćih i stranih doseljenika. Taj nalaz govori u prilog činjenici da se na otocima istodobno odvijaju dva procesa. $S$ jedne strane dominiraju negativni demografski trendovi, dok s druge bilježimo sve intenzivniji turistički razvoj. Iako je teško očekivati značajniju revitalizaciju otočnog prostora, turizam svakako dovodi nove aktere u prostor otoka, a to se posebno odnosi na strano stanovništvo koje, razočarano konzumerističkim vrijednostima u svojim zemljama, pronalazi novi životni smisao u kombinaciji prirodnih i kulturnih bogatstava otoka. Veliki otoci svakako su u povoljnijoj poziciji zbog većeg broja stanovnika, veće gustoće društvenih odnosa te više sadržaja i infrastrukturne opremljenosti.

Budući da je posrijedi studija slučaja na jednom otoku, ovo istraživanje ima svojih ograničenja. U prvom redu, uzorak nije bio reprezentativan. Nadalje, otok Korčula pripada skupini velikih kanalskih otoka i pojave koje opisujemo u radu možda nisu vidljive na nekome drugome, manjem, udaljenijem hrvatskom otoku, te rezultate treba shvatiti uvjetno. U nekom budućem istraživanju svakako bi trebalo pokušati utvrditi točni broj doseljenika kako domaćih tako i stranih na otoku Korčuli te usporediti rezultate ovog istraživanja s rezultatima istraživanja provedenim na nekim drugim hrvatskim otocima, odnosno tradicionalno iseljeničkom području. Također, veću istraživačku pozornost valjalo bi posvetiti i integraciji doseljenika u zajednici.

\section{LITERATURA}

Bara, M. (2013). Povratne umirovljeničke migracije na hrvatskim otocima, Migracijske $i$ etničke teme, 29 (2): 201-224, doi: https://doi.org/10.11567/met.29.2.4

Bell, M. i Ward, G. (2000). Comparing temporary mobility with permanent migration, Tourism Geographies, 2 (1): 87-107, doi: https://doi.org/10.1080/146166800363466

Benson, M. (2010). The Context and Trajectory of Lifestyle Migration, European Societies, 12 (1): 45-64, doi: https://doi.org/10.1080/14616690802592605

Benson, M. i O'Reilly, K. (ur.). (2009a). Lifestyle Migration: Expectations, Aspirations and Experiences. Farnham: Ashgate Publishing, Ltd.

Benson, M. i O'Reilly, K. (2009b). Migration and the search for a better way of life: a critical exploration of lifestyle migration, The Sociological Review, 57 (4): 608-625, doi: https://doi.org/10.1111/j.1467-954X.2009.01864.x

Bokan, N. (2012). Konceptualni pristupi ekološkim mikrosocijalnim zajednicama: Studija slučaja u Hrvatskoj (Doktorska disertacija). Zagreb: Sveučilište u Zagrebu, Filozofski fakultet. 
Bolzman, C., Fibbi, R. i Vial, M. (2006). What To Do After Retirement? Elderly Migrants and the Question of Return, Journal of Ethnic and Migration Studies, 32 (8): 1359-1375, doi: https://doi.org/10.1080/13691830600928748

Böröcz, J. (1996). Leisure Migration: A Sociological Study on Tourism. Oxford: Pergamon.

Boyle, P., Halfacree, K. H. i Robinson, V. (1998). Exploring Contemporary Migration (1. izdanje). Harlow: Routledge.

Božić, S. (2001). Posljednja avantura: umirovljeničke migracije, klima i »ugodnosti«, Migracijske i etničke teme, 17 (4): 311-326.

Božić, S. (2006). The Achievement and Potential of International Retirement Migration Research: The Need for Disciplinary Exchange, Journal of Ethnic and Migration Studies, 32 (8): 1415-1427, doi: https://doi.org/10.1080/13691830600928805

Burgess, C. (2004). (Re)constructing identities: international marriage migrants as potential agents of social change in a globalising Japan, Asian Studies Review, 28 (3): 223-242, doi: https://doi.org/10.1080/1035782042000291079

Čapo Žmegač, J. (2010). Različiti pristupi povratnim migracijama: primjer Hrvatske, Studia ethnologica Croatica, 22 (1): 11-38.

Čolić, S. i Sujoldžić, A. (1995). Neki aspekti i pretpostavke akulturacije prognanih i izbjeglih obitelji na otoku Hvaru, Migracijske i etničke teme, 11 (1): 37-52.

Cetinić, M. (1989). Korčula u revolucionarnom radničkom pokretu, narodnooslobodilačkoj borbi i socijalističkoj revoluciji: 1919-1945. Korčula: Grafički zavod Hrvatske.

Charsley, K. (2014). Marriage Migration, u: B. Anderson i M. Keith (ur.). Migration: The COMPAS Anthology. Oxford: COMPAS, http://compasanthology.co.uk/wp-content/ uploads/2014/04/COMPASMigrationAnthology.pdf (10.12.2017.).

Crkvenčić, I., Feletar, D., Malić, A., Počakal, M. i Riđanović, J. (1984). Geografske osnove suvremenih promjena zapadnog dijela otoka Korčule, Hrvatski geografski glasnik, 46 (1): 81-107.

Favell, A. i Recchi, E. (2009). Pioneers of European integration: an introduction, u: E. Recchi i A. Favell (ur.). Pioneers of European Integration: Citizenship and Mobility in the EU. Cheltenham: Edward Elgar Publishing, 1-25, doi: https://doi. org/10.4337/9781849802314.00006

Gardner, K. (2002). Age, Narrative and Migration: The Life Course and Life Histories of Bengali Elders in London. London: Berg Publishers, doi: https://doi.org/10.5040/9781474214278

Gosnell, H. i Abrams, J. (2011). Amenity migration: diverse conceptualizations of drivers, socioeconomic dimensions, and emerging challenges, GeoJournal, 76 (4): 303-322, doi: https://doi.org/10.1007/s10708-009-9295-4

Hoey, B. A. (2006). Grey Suit or Brown Carhartt: Narrative Transition, Relocation and Reorientation in the Lives of Corporate Refugees, Journal of Anthropological Research, 62 (3): 347-371, doi: https://doi.org/10.3998/jar.0521004.0062.303

Hoey, B. A. (2009). Pursuing the Good Life: American Narratives of Travel and a Search for Refuge, u: M. Benson i K. O'Reilly (ur.). Lifestyle Migration: Expectations, Aspirations and Experiences. Farnham: Ashgate Publishing, Ltd, 31-50.

Hoey, B. A. (2014). Theorising the 'Fifth Migration' in the United States: Understanding Lifestyle Migration from an Integrated Approach, u: M. Benson i N. Osbaldiston (ur.). Understanding Lifestyle Migration: Theoretical Approaches to Migration and the Quest for a Better Way of Life. Hampshire, England: Palgrave Macmillan, 71-91, doi: https://doi.org/10.1057/9781137328670_4 
Hunter, A. (2011). Theory and practice of return migration at retirement: the case of migrant worker hostel residents in France, Population, Space and Place, 17 (2): 179-192, doi: https://doi.org/10.1002/psp.610

King, R. (2002). Towards a new map of European migration, International Journal of Population Geography, 8 (2): 89-106, doi: https://doi.org/10.1002/ijpg.246.

King, R. (2012). From life-stage to lifestyle migration: British international retirement migration to the Mediterranean, MIM Research Seminar 5, Malmö University, November 15, 2012, https://www.mah.se/upload/Forskningscentrum/MIM/2012\%20 Seminars/121115\%20PP\%20RK\%20MIM\%20Seminar\%205.pdf (10.5.2015)

King, R. i Christou, A. (2010). Cultural geographies of counter-diasporic migration: perspectives from the study of second-generation 'returnees' to Greece, Population, Space and Place, 16 (2): 103-119, doi: https://doi.org/10.1002/psp.543.

King, R., Warnes, T. i Williams, A. M. (2000). Sunset Lives: British Retirement Migration to the Mediterranean. Oxford: Berg.

Lajić, I. (1992). Stanovništvo dalmatinskih otoka. Zagreb: Consilium - Institut za migracije i narodnosti Sveučilišta u Zagrebu.

Lajić, I. i Mišetić, R. (2013). Demografske promjene na hrvatskim otocima na početku 21. stoljeća, Migracijske i etničke teme, 29 (2): 169-199, doi: https://doi.org/10.11567/ met.29.2.3

Mai, N. i King, R. (2009). Love, Sexuality and Migration: Mapping the Issue(s), Mobilities, 4 (3): 295-307, doi: https://doi.org/10.1080/17450100903195318

Merali, N. (2008). Theoretical Frameworks for Studying Female Marriage Migrants, Psychology of Women Quarterly, 32 (3): 281-289, doi: https://doi.org/10.1111/j.14716402.2008.00436.x

Mesić, M. (2002). Međunarodne migracije. Tokovi i teorije. Zagreb: Zavod za sociologiju -Filozofski fakultet u Zagrebu.

Miletić, G.-M. (2011). U potrazi za drugim prostorom. Zagreb: Institut društvenih znanosti Ivo Pilar.

Mirošević, F. (2006). Iseljavanje s otoka Korčule u razdoblju od 1921. do 1931. godine, Godišnjak grada Korčule, 11: 317-333.

Mirošević, L. (2008). Društveno-geografska preobrazba zapadnog dijela otoka Korčule, Geoadria, 13 (2): 155-185, doi: https://doi.org/10.15291/geoadria.562

O'Reilly, K. (2003). When is a tourist? The articulation of tourism and migration in Spain's Costa del Sol, Tourist Studies, 3 (3): 301-317, doi: https://doi. org/10.1177/1468797603049661

O'Reilly, K. i Benson, M. (2009). Lifestyle Migration: Escaping to the Good Life?, u: M. Benson i K. O'Reilly (ur.). Lifestyle Migration: Expectations, Aspirations and Experiences. Farnham: Ashgate Publishing, Ltd, 1-13.

Peračković, K. (2001). Stavovi povratnih migranata o privatizaciji u Hrvatskoj (Magistarski rad). Zagreb: Sveučilište u Zagrebu, Filozofski fakultet.

Podgorelec, S. i Klempić Bogadi, S. (2013). Gradovi potopili škoje - promjene u malim otočnim zajednicama. Zagreb: Institut za migracije i narodnosti, doi: https://doi. org $/ 10.11567 / 2013.01$

Ryan, L. i Sales, R. (2013). Family Migration: The Role of Children and Education in Family Decision-Making Strategies of Polish Migrants in London, International Migration, 51 (2): 90-103, doi: https://doi.org/10.1111/j.1468-2435.2010.00652.x 
Stiperski, Z., Malić, A. i Kovačević, D. (2002). Međuzavisnost dostupnosti, gospodarstva i revitalizacije hrvatskih otoka, Sociologija i prostor, 39 (1-4): 153-168.

Trundle, C. (2009). Romance Tourists, Foreign Wives or Retirement Migrants? Crosscultural Marriage in Florence, Italy, u: M. Benson i K. O’Reilly (ur.). Lifestyle Migration: Expectations, Aspirations and Experiences. Farnham: Ashgate Publishing, Ltd., 51-67.

Van Hear, N. (2010). Theories of Migration and Social Change, Journal of Ethnic and Migration Studies, 36 (10): 1531-1536, doi: https://doi.org/10.1080/136918 3x.2010.489359

Vathi, Z. (2011). The Children of Albanian Migrants in Europe: Ethnic Identity, Transnational Ties and Pathways of Integration (Doktorska disertacija). Brighton: University of Sussex,

Williams, A. M. i Hall, C. M. (2000). Tourism and migration: New relationships between production and consumption, Tourism Geographies, 2 (1): 5-27, doi: https://doi. org/10.1080/146166800363420

\section{IZVORI}

Popis stanovništva, kućanstava i stanova 2011. godine, Stanovništvo prema državljanstvu po gradovima i općinama, Državni zavod za statistiku, Zagreb, 2013, http://www.dzs.hr/

Stanovništvo prema starosti i spolu po naseljima; Naselja i stanovništvo RH 1857. - 2001., Državni zavod za statistiku, Zagreb, https://www.dzs.hr/hrv/dbhomepages/ naselja\%20i\%20stanovnistvo\%20republike\%20hrvatske/Naselja\%20i\%20 stanovnistvo\%20Republike\%20Hrvatske.htm 


\title{
Moving to an Island - Contemporary Migrations to the Island of Korčula
}

\author{
Marica Marinović Golubić
}

SUMMARY

Long-term emigration of the island population has somehow blurred the fact that islands at the same time attract certain groups of newcomers (although not in large numbers). In this paper, through the case study of Korčula, the phenomenon of recent immigration to the Croatian islands (occurring after year 2000) is explored. This new population certainly attracts attention because of its possible impact on the social revitalisation of small island communities. The island of Korčula is situated in the southern part of the Croatian Adriatic coast. It is populated with around 15 thousand inhabitants in five main settlements. The main local economic activities are tourism, fishing, olive and grapevine growing. The island rhythm is seasonal with huge differences between the summer and winter months. The focus of this research was on the international and internal immigrants who spent the majority of the year on the island. The author was interested in the reasons that bring them to places that are experiencing negative demographic trends and are dominated by outmigration. The aim was to study the reasons and the context of migrants' relocation decisions.

The theoretical background of the paper relies on the approaches that emphasise the non-economic reasons for migration (King, 2002), and migration as a result of lifestyle change (Benson \& O'Reilly, 2009a). It is argued that the usual theories of labour migrants and economically motivated migrations cannot sufficiently explain the interest in migrating to areas such as islands, which are depopulated, but with valuable cultural and environmental resources. There are more and more people moving to other places and the reasons they emphasise are pleasant climate, a more beautiful or healthier environment, a better or just different lifestyle. At the same time this redefines the attractiveness of peripheral locations.

The research approach was qualitative and included fieldwork and interviews with 37 island newcomers (migrants). Three basic groups were identified according to their main connection with the island: a) return migrants (13 respondents), b) marriage migrants (12 respondents) and c) migrants without prior marital or family connections with the island (12 respondents). Return migrants have been identified in the previous similar studies as the most common immigrant group on the Croatian islands. The majority of them had left the island while in their 20 s and went to mainland Croatia, different European countries, but also to overseas and came back to island upon retirement. They are not interested in seeking paid employment and the economic conditions on the island do not affect their socio-economic status, as their accumulated savings or foreign pensions allow them to live a pleasant, but not luxurious life. Their return to the island is also a quest for new daily routines that could replace their earlier obligations connected to paid work, which is why they often engage themselves in traditional activities, such as olive growing, winemaking, agriculture without commercialisation - just for their own needs. In addition to the return retirement migrants of the first generation, the results also identified second-generation migrants who return in work-active age. They are highly educated and live mostly with children (younger than 18). Most of them are employed 
or self-employed and have numerous initiatives on how to improve the island's social conditions. Very often, they actively engage in the local community (politically, socially). Although the base of potential return migrants in traditional emigration areas is large, it is not to be expected that they will bring the desired demographic dynamics to the island community since there are still too few second-generation migrants returning. In the case of the island of Korčula, the circumstance that makes the return somehow easier is that the island is relatively large (compared to other Croatian islands) and provides organised primary health care and other basic services (primary and secondary schools, public administration offices, public transport, kindergartens, banks, post offices, supermarkets, restaurants, cafés, etc.).

As for the second newcomer group, marriage migrants, there were always foreign brides on the island - but the distance was smaller in the past. They mostly came from nearby villages or towns. Today, they have different national and international origins. There are two main ways of coming: by marrying an islander working in a foreign country or on a ship or by meeting and marrying an islander after a tourist or business visit to the island.

The third group, migrants without prior marital or family connections with the island, can be further divided into two sub-groups: labour migrants who occupied the previously underdeveloped small business niches on the island, such as diving or health services, and ex-tourists who saw the island as an ideal location for starting a new life.

What all three migrant groups have in common is their quest for small, safe communities with potentials in which they would be able to find more balance between work and enjoyment, work and family, and a closer connection to the community and nature.

KEY WORDS: Island of Korčula, island, immigration, lifestyle migration, return retirement migration, return migration 
